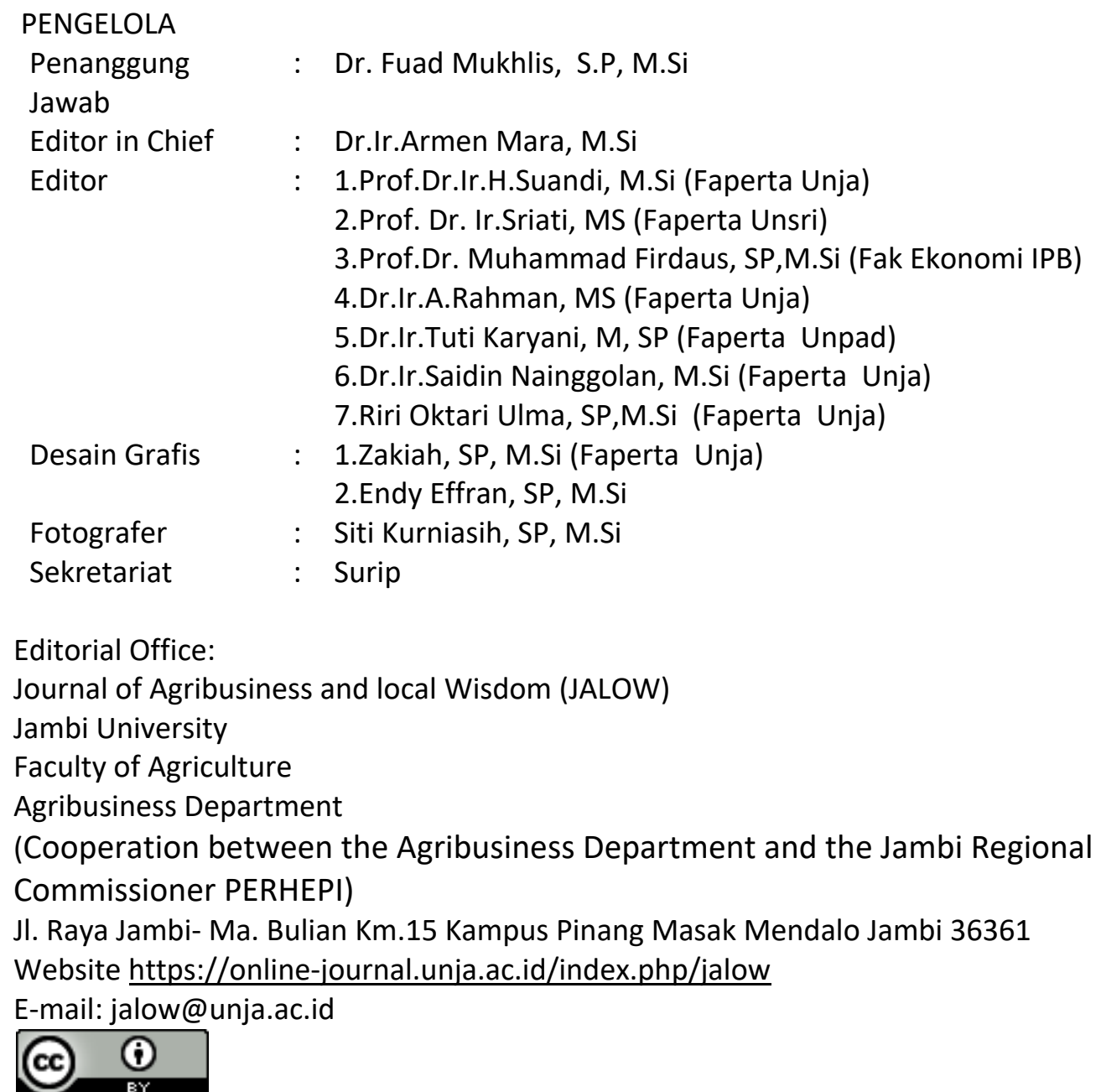

This work is licensed under a Creative Commons Attribution 4.0 International License. 


\section{Assalamualaikum wbwb}

\section{PENGANTAR}

Kondisi agribisnis tahun 2020 ini agak berbeda dengan tahun sebelumnya. Kebijakan penanggulangan Covid19 seperti "dirumah Aja, lockdown lokasi, Isolasi Mandiri, PSBB (Pembatasan Sosial Berskala Besar), dan Herd Immunity" telah merubah pola aktivitas masyarakat, khususnya di Kota-kota. Sebelumnya, berkejar2an dengan waktu untuk meningkatkan pendapatan dengan jalan menambah produktivitas dan menekan biaya telah dikagetkan oleh adanya ancaman pandemi Covid19 yang ada dimana-mana, semangat berkejar-kejaran tersebut kendur seketika.

Kegiatan perdagangan di Kota-kota besar maupun kota kecil telah mengalami kelesuan untuk semua lapisan, mulai dari pedagang kecil mikro, pedagang asongan atau gerobak, pedagang toko, mini market sampai perdagangan berskala besar, super market, dan mallmall. Hal ini menyebabkan terjadinya pengangguran, berkurangnya pendapatan masyarakat dan menurun drastisnya penerimaan pemerintah dari pajak. Selama masa isolasi, para konsumen melakukan belanja dengan sangat hati-hati. Pihak produsen merasakan berkurangnya permintaan. Oleh karena itu, walaupun kebijakan Covid19 tidak menghambat aktivitas produksi pertanian di lahan secara langsung namun karena permintaan berkurang maka berkurang pula pendapatan petani yang mengusahakan kebun atau sawah.

Kebiasaan konsumen yang selama ini lebih banyak makan di luar rumah berubah menjadi lebih banyak makan di rumah sendiri, masak sendiri atau pesan antar. Berbelanja yang semula mencari tempat2 yang banyak di kerumuni orang berubah ke tempat yang tidak ada kerumunannya, artinya rasa enak dan harga murah tidak lagi menjadi patokan utama bagi konsumen. Mereka lebih mengutamakan sehat dan terjamin dalam proses pembuatannya. Kesadaran adanya ancaman bahaya serangan Covid19 terhadap nyawa setiap orang telah menyebabkan berubah nya psikologi dan sosial masyarakat. Sebelumnya berpikir materialis dan untung rugi dari setiap kerja, sekarang mulai nampak adanya kepedulian terhadap perintah agama melaksanakan sholat dan bersedekah. Mulai terlihat adanya aktivitas sosial di tengah-tengah kota, ada kegiatan membagikan nasi bungkus kepada kaum duafah dan lapisan bawah, kegiatan membagikan sembako, membagikan ampelop berisi uang kertas, sampai pada aktivitas memberikan tip berupa uang dalam setiap kali berbelanja di pedagang-pedagang kecil.

Harapan untuk semua aktivitas-aktivitas positif tersebut berlangsung tidak sementara tapi menjadi karakter bagi setiap orang. Kalau aktivitas sosial ini terus dipertahankan oleh pelaku yang telah memulai nya tentu akan diikuti juga oleh yang lainnya. Diharapkan juga setiap pelaku agribisnis berskala kecil, baik yang disektor produksi pertanian maupun sektor industri pengolahan dan perdagangan dapat mengantisipasi perubahan prilaku konsumen tersebut dengan perubahan pola produksi yang sesuai sehingga peluang bisnis yang terlepas dari pola sebelumnya dapat ditangkap.

Demikian semoga JALOW untuk penerbitan ini bermanfaat untuk kita semua aamiin ya robbal aalamiin.

Waalaikumsalam wbwb

Editor in Chief

Dr.Ir.Armen Mara,M.Si 
DAFTAR ISI

\begin{tabular}{|c|c|c|}
\hline 1 & $\begin{array}{l}\text { ANALISIS RESPON PENAWARAN KOMODITI KEDELAI } \\
\text { DI KABUPATEN TANJAB TIMUR } \\
\text { Oleh Edison }\end{array}$ & $1-10$ \\
\hline 2 & 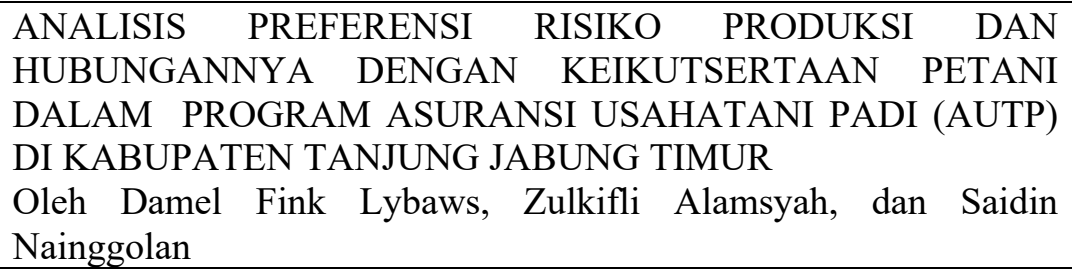 & $11-27$ \\
\hline 3 & $\begin{array}{l}\text { ANALISIS USAHA IKAN HIAS AIR TAWAR DI KOTA JAMBI (ANALYSIS } \\
\text { OF FRESH WATER ORNAMENTAL FISH IN JAMBI CITY) } \\
\text { Dody Hadisaputra, Ernawati, Suandi }\end{array}$ & $28-40$ \\
\hline 4 & $\begin{array}{l}\text { ANALISIS FAKTOR-FAKTOR YANG MEMPENGARUHI PRODUKSI } \\
\text { BOKAR (BAHAN OLAH KARET) DI KABUPATEN BATANGHARI } \\
\text { Oleh Elisabeth Lumban Gaol, Armen Mara, dan Riri Oktari UIma }\end{array}$ & $41-52$ \\
\hline 5 & $\begin{array}{l}\text { ANALISIS PENGAMBILAN KEPUTUSAN UNTUK PEMBELIAN } \\
\text { MAKANAN KEMASAN BERLOGO HALAL MUI (STUDI KASUS IBU } \\
\text { RUMAH TANGGA DI PERUMAHAN AUR DURI DAN PERUMNAS KOTA } \\
\text { BARU, KOTA JAMBI) } \\
\text { Oleh Putri Hana Jusia, Saad Murdy, Lavlinesia }\end{array}$ & $53-66$ \\
\hline 6 & \begin{tabular}{lcccr} 
STRATEGI & ADAPTASI & PETANI & DALAM & \multicolumn{2}{l}{ MENGHADAPI } \\
RENDAHNYA & HARGA & JUAL & KELAPA & SAWIT DI \\
KECAMATAN & SUNGAI & BAHAR & KABUPATEN & MUARO \\
JAMBI & & & \\
Oleh Fiona Andini ${ }^{1}$ ), Fuad Muchlis $^{2}$ ), Aulia Farida 2)
\end{tabular} & $67-73$ \\
\hline 7 & \begin{tabular}{lcllr} 
KOLABORASI & DALAM & PENGELOLAAN & \multicolumn{2}{c}{ PERKEBUNAN } \\
KELAPA SAWIT & RAKYAT & (STUDI KASUS: KUD & LUBUK \\
KARYA DAN & KUD & KAMPUNG & SURAU & KAB. \\
DHARMASRAYA & & & & \\
Oleh Yulistriani & & & & \\
\end{tabular} & $74-81$ \\
\hline 8 & $\begin{array}{l}\text { KEPUTUSAN PETANI SAWIT DALAM MENGKONVERSI } \\
\text { LAHAN KELAPA SAWIT MENJADI LAHAN PADI SAWAH DI } \\
\text { KECAMATAN BATANG ASAM KABUPATEN } \\
\text { TANJUNG JABUNG BARAT } \\
\text { Oleh Krielson Ompusunggu1), Arsyad Lubis2, Siti Kurniasih2 }\end{array}$ & $82-88$ \\
\hline 9 & $\begin{array}{l}\text { KAITAN BIAYA DAN TEKNIK PEREMAJAAN } \\
\text { KELAPA SAWIT RAKYAT } \\
\text { Oleh Nur Imdah Minsyah }\end{array}$ & $89-99$ \\
\hline 10 & $\begin{array}{l}\text { STRATEGI RANTAI PASOK KELAPA SAWIT DI PROVINSI } \\
\text { SUMATERA BARAT } \\
\text { Oleh Rahma Dzulqa1*), Rika Ampuh Hadiguna2) }\end{array}$ & 100-108 \\
\hline
\end{tabular}




\title{
ANALISIS FAKTOR-FAKTOR YANG MEMPENGARUHI PRODUKSI BOKAR (BAHAN OLAH KARET) DI KABUPATEN BATANGHARI
}

\author{
Elisabeth Lumban $\mathrm{Gaol}^{1)}$, Armen Mara ${ }^{2)}$ dan Riri Oktari Ulma ${ }^{2)}$ \\ 1) Alumni Program Studi Agribisnis Fakultas Pertanian Universitas Jambi \\ 2) Staf Pengajar Jurusan Agribisnis Fakultas Pertanian Universitas Jambi \\ Email : elisabeth_lumbangaol@yahoo.com
}

\begin{abstract}
This study aims to (1) the progress bokar production, the land area to produce crops, the land area of old plants, the amount of labor, rainfall and number of days of rain in Batanghari regency during the period 2001 to 2015 (2) Determine how much influence hectarage produce, the land area of old plants, the amount of labor, rainfall and number of days of rain to the production bokar in Batanghari regency during the period 20012015. The data used in this research is secondary data time series (time series) for 5 years (2001-2015). Test data is stationary using the unit root test Phillip Perron (PP). The analysis model is a linear regression. The test model using normality test, multicollinearity, heteroscedasticity test and autocorrelation test. The results showed that the area of cultivated land, the area of old plantation, the amount of labor, rainfall and amount of rain days together significantly affect the production of bokar in Batanghari regency. Partially, the factors that have a positive and significant effect on bokar production in Batanghari Regency are the area of cultivated land and the amount of labor. Factor area of old crop land have negative and significant effect, while rainfall factor and rainy day partially have no significant effect on bokar production.
\end{abstract}

\section{Keywords: Production, Bokar, Multiple Linear Regression Analysis}

\section{PENDAHULUAN}

Karet merupakan salah satu hasil perkebunan yang mempunyai peran cukup penting dalam kegiatan perekonomian di Indonesia. Indonesia mempunyai luas areal perkebunan karet terbesar di dunia seluas 3.445 .000 hektar, namun produktivitasnya tergolong rendah yakni $986 \mathrm{~kg} / \mathrm{ha} /$ Tahun sangat kontras dengan produktivitas karet Thailand yang mencapai $1600 \mathrm{~kg} / \mathrm{ha} / T a h u n$ sehingga belum memberikan hasil yang maksimal bagi devisa negara dan mendominasi perkaretan dunia (Direktorat Jenderal Industri Agro, 2013). Hal ini dikemukakan pula oleh pendapat Parhusip (2008) yang menyatakan, dengan rendahnya produktivitas lahan, posisi Indonesia yang diharapkan sebagai Market Leader di pasar Internasional sulit terwujud walaupun memiliki luas lahan yang terbesar didunia.

Salah satu penghasil komoditas karet alam terbesar Indonesia adalah Provinsi Jambi. Perhatian terhadap komoditas karet rakyat menjadi penting di Provinsi Jambi mengingat potensi lahan perkebunan yang sangat besar. Perkembangan luas areal, produksi dan produktivitas usahatani karet di Provinsi Jambi dalam kurun waktu lima tahun terakhir (2010-2014) setiap tahunnya mengalami peningkatan. Pada Tahun 20102014, laju pertumbuhan produksi perkebunan karet di Provinsi Jambi sebesar 15,2\%, peningkatan produktivitas sebesar $11,6 \%$, sedangkan untuk peningkatan luas lahan sebesar 2,64\%. Luas tanaman karet di Provinsi Jambi pada Tahun 2014 mencapai luas 
662.213 Ha, namun $125.925 \mathrm{Ha}$ atau $18,9 \%$ dari luas total merupakan tanaman karet tua dan rusak yang perlu ditindak lanjuti oleh pemerintah.

Provinsi Jambi merupakan provinsi dengan luas areal perkebunan karet terluas kedua setelah provinsi Sumatera Selatan dengan areal sebesar $454.178 \mathrm{Ha}$ atau sekitar $15,02 \%$ dari seluruh luas areal perkebunan karet di Indonesia. Namun dalam hal ini, produktivitas karet di Provinsi Jambi tergolong masih sangat rendah dibandingkan dengan provinsi lain sehingga produksinya tidak terlalu besar. Provinsi Jambi memiliki produktivitas terendah kelima dari seluruh provinsi penghasil karet yang ada di Indonesia atau sebesar $894 \mathrm{~kg} / \mathrm{ha} / T a h u n$, sedangkan untuk produktivitas tertinggi yaitu provinsi Sulawesi Barat dengan luas lahan 1.205 Ha mampu mencapai mencapai produktivitas $1.390 \mathrm{~kg} / \mathrm{ha} /$ Tahun.

Menurut data Dinas Perkebunan Provinsi Jambi Tahun 2013, terdapat 9 kabupaten yang mengusahakan usahatani karet di Provinsi Jambi. Kabupaten Batanghari merupakan kabupaten yang menempati luas tanam terbesar keempat di Provinsi Jambi dengan memiliki luas tanam $112.981 \mathrm{Ha}$ atau $17,1 \%$ dari total luas areal perkebunan karet di Jambi. Akan tetapi, luas pertanian karet di Kabupaten Batanghari tidak diiringi dengan rata-rata hasil produksi karet yang baik. Produktivitas tanaman karet di Kabupaten Batanghari sebesar $941 \mathrm{Kg} / \mathrm{Ha}$ masih tergolong rendah bila dibandingkan dengan Kabupaten Muaro Jambi dengan luas tanam 55.867 Ha yang produktivitasnya mampu mencapai $1.009 \mathrm{~kg} / \mathrm{ha}$.

Produktivitas karet di Kabupaten Batanghari masih dapat ditingkatkan lagi dengan memperhatikan faktor-faktor yang mempengaruhi produksi karet. Banyak hal yang mempengaruhi rendahnya produksi karet beberapa diantaranya kondisi umur tanaman dan keadaan iklim. Di dalam penelitian ini faktor - faktor yang akan dianalisa mempengaruhi produksi bokar di Kabupaten Batanghari diantaranya luas lahan tanaman menghasilkan, luas lahan tanaman tua, jumlah tenaga kerja, curah hujan, dan jumlah hari hujan. Enam puluh satu persen dari total areal karet merupakan tanaman tua menghasilkan, ditambah lagi dengan usaha peremajaan karet tua yang sangat lambat, sehingga masih banyak lahan tua tanaman karet yang berproduksi namun dengan hasil yang semakin lama semakin menurun. Pada Tahun 2011, pendapatan petani karet di Kabupaten Batanghari pernah mengalami penurunan drastis karena menurunnya produksi getah akibat musim penghujan. Menurut petani karet di Kabupaten Batanghari, pada saat musim hujan produksi karet mereka dapat menurun antara 30-50 persen. Penurunan terjadi karena petani kesulitan menyadap pohon karetnya. Getah yang disadap tidak boleh bercampur dengan air hujan, karena dapat merusak getah. Petani hanya bisa menyadap saat hujan tidak datang (Tribunnews, 2011). Selain itu curah hujan mempengaruhi tinggi rendahnya hasil getah yang dikeluarkan pohon karet.

Perkebunan karet rakyat di Kabupaten Batanghari masih memiliki peluang yang cukup besar untuk dapat dikembangkan secara lebih luas pada semua subsistem. Besarnya potensi sumber daya yang dimiliki seperti lahan, iklim, dan tenaga kerja yang memadai akan meningkatkan peluang tersebut. Oleh karena itu perlu diketahui bagaimana perkembangan faktor-faktor yang mempengaruhi serta bagaimana pengaruhnya terhadap produksi bokar.

Tujuan penelitian ini adalah: 1) Untuk mengetahui perkembangan produksi bokar, luas lahan tanaman menghasilkan, luas lahan tanaman tua, jumlah tenaga kerja, curah hujan dan jumlah hari hujan di Kabupaten Batanghari selama periode 2001-2015. 2) Untuk mengetahui seberapa besar pengaruh luas lahan tanaman menghasilkan, luas lahan tanaman tua, jumlah tenaga kerja, curah hujan dan jumlah hari hujan terhadap produksi bokar di Kabupaten Batanghari selama periode 2001-2015. 


\section{METODE PENELITIAN}

Penelitian ini difokuskan pada faktor-faktor yang mempengaruhi produksi bokar di Kabupaten Batanghari yaitu faktor luas lahan tanaman tua, luas lahan tanaman menghasilkan, jumlah tenaga kerja, jumlah curah hujan, dan jumlah hari hujan. Data yang digunakan dalam penelitian ini adalah data sekunder runtut waktu (time series). Data time series merupakan sekumpulan data dari suatu fenomena tertentu yang didapat dalam beberapa interval waktu tertentu (Husein Umar, 1998). Rentang waktu yang digunakan dalam penelitian ini adalah lima belas tahun terakhir (2001-2015). Data diperoleh dari instansi pemerintah terkait dengan penelitian yang diteliti. Instansi-instansi yang terkait dengan penelitian ini adalah Badan Pusat Statistik (BPS) Provinsi Jambi, Dinas Perkebunan Provinsi Jambi, dan BMKG (Badan Meteorologi Klimatologi dan Geofisika) Provinsi Jambi.

Analisis yang digunakan dalam penelitian ini adalah analisis deskripstif dan kuantitatif. Metode deskriptif digunakan untuk melihat perkembangan produksi bokar di Kabupaten Batanghari. Sedangkan metode kuantitatif digunakan untuk menjelaskan pengaruh variabel bebas terhadap variabel terikat berdasarkan angka. Metode analisis yang digunakan pada penelitian ini adalah model analisis regresi linear berganda, dengan model persamaannya dapat dirumuskan dengan model sebagai berikut:

$$
Y=\beta_{0}+\beta_{1} X_{1}+\beta_{2} X_{2}+\beta_{3} X_{3}+\beta_{4} X_{4}+\beta_{5} X_{5}+e
$$

Dimana :

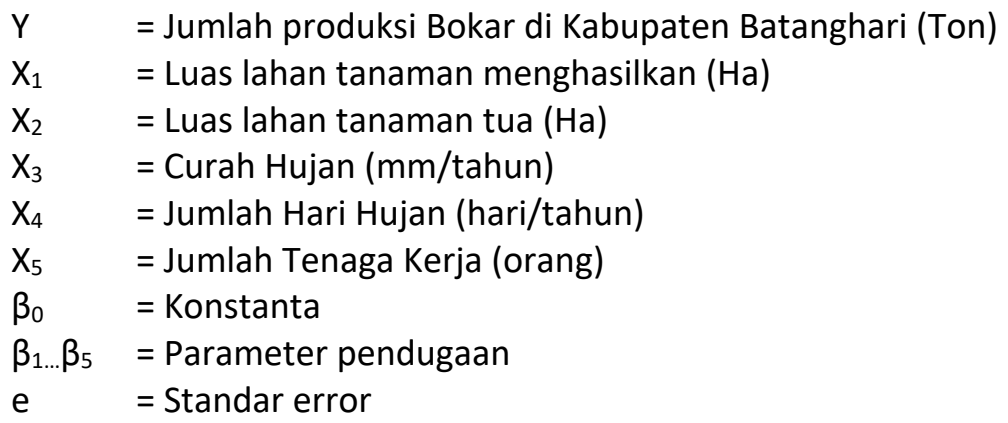

\section{Uji Stasioner (Uji Akar Unit)}

Hal yang akan dilakukan terlebih dahulu dalam pengolahan data adalah melakukan uji stasioneritas data. Stasioneritas suatu data sangatlah penting dalam penggunaan analisis data yang berbentuk time series. Suatu variabel dikatakan stasioner jika nilai rata-rata dan variansnya konstan sepanjang waktu dan nilai kovarian antara dua periode waktu hanya tergantung pada selisih atau selang antara dua periode waktu tersebut bukan waktu sebenarnya ketika kovarian tersebut dihitung (Gujarati, 2003).

Dalam ekonometrika dikenal dengan beberapa pengujian unit root dan data ekonomi makro pada umumnya time series yang rentan dengan ketidak stasioneran, untuk itu sebelumnya dilakukan uji stasioner. Tujuan uji stasioner ini adalah agar meannya stabil dan random error nya $=0$, sehingga model regresi yang diperoleh adalah regresi semu. Pengujian stasioner data dilakukan dengan uji akar unit Phillips-Peron (PP). Pengunaan uji akar Phillips-Perron uji ini lebih baik dibandingkan dengan uji ADF dalam menganalisis data yang mempunyai volatilitas yang tinggi (Agus Widarjono, 2005).

Uji Phillips-Peron (PP) memasukan adanya autokorelasi di dalam variabel ganguan dengan memasukan variabel independen berupa kelambanan diferensi. Phillips-Peron (PP) membuat uji akar unit dengan mengukan metode statistik nonparametrik dalam menjelaskan adanya autokorelasi antara variabel gangguan tanpa memasukan variabel penjelas kelambanan deferensi. Statistik distibutif $t$ tidak mengikuti statistik distributif 
normal tetapi mengikuti distributif statistik PP, sedangkan nilai kritisnya digunakan nilai kritis atau penentuan bentuk linear atau non linear dari model mengikuti prosedur yang dikembangkan oleh McKinnon, White dan Davidson (1983) atau MWD test. Sementara pengujian stasionaritas mengikuti Phillips-Peron (PP) dengan cara membandingkan antara nilai kritisnya yaitu distribusi statistik MacKinnon. Jika nilai absolute statistik PP lebih besar dari nilai kritisnya, maka data yang diamati menunjukan stasioner dan jika sebaliknya nilai absolut statistik PP lebih kecil dari nilai kritisnya maka data tidak stasioner. Langkah-langkah pengujian sebagai berikut:

Hipotesis : $\quad H o=$ data tersebut tidak stasioner pada derajat nol.

$\mathrm{Ha}=$ data tersebut stasioner pada derajat nol.

Pengambilan keputusan dilakukan dengan kriteria :

- Jika PP test statistik > PP tabel (daerah kritis $\alpha=5 \%$ ) maka Ho ditolak, data stasioner pada derajat nol.

- Jika PP test statistik < PP tabel (daerah kritis $\alpha=5 \%$ ) maka Ha ditolak, data tidak stasioner pada derajat nol.

\section{Uji Asumsi Klasik}

Asumsi klasik yang digunakan dalam penelitian ini yaitu uji normalitas, uji multikolinearitas, uji heteroskedastisitas, dan uji autokorelasi. Pengujian normalitas bertujuan untuk menguji apakah model regresi variabel pengganggu atau residual memiliki distribusi normal. Pengujian kenormalan dilakukan dengan memeriksa apakah error term mendekati distribusi normal. Uji ini perlu dilakukan jika jumlah sampel yang digunakan kurang dari $30(\mathrm{n}<30)$. Hipotesis pengujiannya adalah: $\mathrm{H}_{\mathrm{o}}: \alpha=0$, error term terdistribusi normal; $\mathrm{H}_{1}: \alpha \neq 0$, error term tidak terdistribusi normal.

Wilayah kritis penolakan $\mathrm{H}_{0}$ adalah Jarque Bera $(J-B)>X^{2} d f-2$ atau probabilitas (p_value) $<\alpha$, sedangkan daerah penerimaan adalah Jarque Bera $(J-B)>X^{2} d f-2$ atau probabilitas ( $\left.p \_v a l u e\right)>\alpha$. Jika $\mathrm{H}_{0}$ ditolak maka disimpulkan error term tidak terdistribusi normal, sedangkan jika $\mathrm{H}_{0}$ diterima maka disimpulkan bahwa error term terdistribusi normal.

Multikolinearitas dapat dideteksi dengan melihat serius ada tidaknya hubungan antar variabel independen $(\mathrm{X})$ yang dianalisis. Jika terjadi multikolinearitas yang serius di dalam model, maka pengaruh masing-masing variabel independen terhadap variabel dependennya ( $\mathrm{Y}$ ) tidak dapat dipisahkan, sehingga estimasi yang diperoleh akan menyimpang atau bias. Pada penelitian ini akan digunakan uji multikolinearitas dengan melihat nilai Variance Influence Factor (VIF) pada model regresi. Jika VIF lebih kecil dari 1 dan lebih besar daripada 5 serta nilai tolerance dibawah 0,05 , maka variabel tersebut mempunyai persoalan multikolinearitas.

Kemudian uji heteroskedastisitas untuk mengetahui ada atau tidaknya ketidaksamaan varian dari residual pada model regresi. Persyaratan yang harus terpenuhi dalam model regresi adalah ada tidaknya masalah heteroskedastisitas. Pada penelitian ini akan dilakukan dengan uji Breusch-Pagan-Godfrey. Prosedur Breusch-Pagan-Godfrey mengasumsikan bahwa ketika varians residual adalah tidak konstan maka ia akan berhubungan dengan satu atau lebih variabel dalam spesifikasi yang linier. Jika signifikan korelasi kurang dari 0,05 maka model regresi terjadi masalah heteroskedastisitas.

Uji autokorelasi ialah uji yang digunakan untuk mengetahui ada atau tidaknya penyimpangan asumsi klasik autokerelasi, yakni korelasi yang terjadi antara residual pada satu pengamatan dengan pengamatan lain pada model regresi. Autokorelasi dapat diartikan sebagai korelasi sisaan yang satu dengan sisaan lainnya. Biasanya autokorelasi sering terjadi pada data time series. Penyebab utama terjadinya autokorelasi adalah ada variabel penting yang tidak digunakan dalam model. Pendeteksian autokorelasi dapat 
dilakukan dengan melihat probabilitas $O b{ }^{*} R$-squared dengan menggunakan statistik Breusch -Godfrey Serial Correlation LM. Hipotesis dalam uji ini adalah: $\mathrm{H}_{0}: \rho=0$, tidak terdapat autokorelasi; $\mathrm{H}_{1}: \rho \neq 0$, terdapat autokorelasi. Wilayah kritik penolakan $\mathrm{HO}$ adalah probabilitas $O b s^{*} R$-squared $<\alpha$ sedangkan wilayah penerimaan $\mathrm{HO}$ adalah probabilitas Obs*R-squared $>\alpha$. Jika HO ditolak maka terjadi autokorelasi (positif atau negatif) dalam model. Sebaliknya jika HO diterima maka tidak ada autokorelasi dalam model.

\section{Uji Kriteria Statistik}

Kriteria statistik dilakukan untuk mengetahui apakah variabel independen atau bebas berpengaruh secara nyata atau tidak terhadap variabel dependennya atau tak bebas. Kriteria statistik pada pengujian model ini meliputi uji koefisien Determinasi $(R$ Squared $\left./ R^{2}\right)$, Uji statistik $F$ serta Uji t. Koefisien determinasi $\left(R^{2}\right)$ pada dasarnya digunakan untuk mengukur seberapa besar kemampuan model menjelaskan variasi variabel dependen. Jadi, koefiesien determinasi sebenarnya mengukur besarnya presentase pengaruh semua variabel independen dalam model regresi terhadap variabel dependennya. Besarnya nilai koefisien determinasi berupa presentase variasi nilai variabel dependen yang dapat dijelaskan oleh model regresi.

Untuk mengetahui persentase sumbangan variabel bebas terhadap produksi bokar serta untuk mengetahui apakah hasil pendugaan regresi tersebut cukup baik atau tidak digunakan ukuran koefisien determinasi berganda yang berkorelasi $\left(\mathrm{R}^{2}\right)$ dengan rumus :

$$
\begin{aligned}
& \mathrm{R}^{2}=\frac{b i \sum x i y i}{\sum y i^{2}} \\
& \text { dimana }: \\
& \mathrm{R}^{2} \quad=\text { Koefisien Determinasi } \\
& \mathrm{y}_{\mathrm{i}} \quad \text { Jumlah simpangan suatu variabel dari nilai rata }- \text { rata }\left(\mathrm{Y}_{\mathrm{i}}-\mathrm{Y}\right) \\
& \mathrm{x}_{\mathrm{i}} \quad \text { J Jumlah variabel deviasi ke-i dari rata-rata }\left(\mathrm{X}_{\mathrm{i}}-\mathrm{X}\right) \\
& \mathrm{bi} \quad=\text { Koefisien regresi variabel ke-i } \\
& \mathrm{yi}^{2} \quad \text { = Jumlah kuadrat simpangan variabel ke-i dari nilai rata-rata }\left(\mathrm{Y}_{\mathrm{i}}-\mathrm{Y}\right)^{2}
\end{aligned}
$$

Nilai $R^{2}$ terletak antara 0 dan 1 yaitu $0 \geq R^{2} \geq 1$. Bila nilai $R^{2}$ mendekati 0 berarti sedikit sekali sumbangan variabel $X$ terhadap variabel $Y$. Jika $R^{2}$ bergerak mendekati 1 berarti semakin besar sumbangan variabel $X$ terhadap variabel $Y$ (Gujarati, 2010).

Uji statistik $\mathrm{F}$ pada dasarnya menunjukkan apakah semua variabel independen atau bebas yang dimasukkan dalam model mempunyai pengaruh secara bersama-sama terhadap variabel dependen (Priyatno, 2014). Dilakukan dengan menggunakan tingkat signifikansi sebesar 0,05. Kriteria penerimaan hipotesis dan penarikan kesimpulan hipotesis antara lain:

1. Jika $\mathrm{F}$ hitung $<\mathrm{F}$ tabel maka $\mathrm{H}_{0}$ diterima.

2. Jika $\mathrm{F}$ hitung $>\mathrm{F}$ tabel maka $\mathrm{H}_{0}$ ditolak (Priyatno, 2014).

Atau berdasar signifikansi :

3. Jika signifikansi $>0,05$ maka $\mathrm{H}_{0}$ diterima.

4. Jika signifikansi $<0,05$ maka $\mathrm{H}_{0}$ ditolak (Priyatno, 2014).

Ho : Tidak ada pengaruh yang signifikan antara luas lahan tanaman menghasilkan, luas lahan tanaman tua, jumlah tenaga kerja, curah hujan, dan jumlah hari hujan (variabel independent) terhadap produksi bokar (variabel dependent). 
$\mathrm{H}_{1}$ : Ada pengaruh yang signifikan antara luas lahan tanaman menghasilkan, luas lahan tanaman tua, jumlah tenaga kerja, curah hujan, dan jumlah hari hujan (variabel independent) terhadap produksi bokar (variabel dependent).

Uji signifikansi parameter individual (uji t) digunakan untuk menguji seberapa jauh pengaruh suatu variabel independen secara individual dalam menerangkan variasi variabel dependen (Priyatno, 2014). Pengujian ini dilakukan dengan menggunakan significance level 0,05 . Kriteria penerimaan hipotesis dan penarikan kesimpulan hipotesis antara lain: 1) Jika signifikansi $>0,05$ maka $\mathrm{H}_{0}$ diterima; 2) Jika signifikansi $<0,05$ maka $\mathrm{H}_{0}$ ditolak (Priyatno, 2014)

\section{HASIL DAN PEMBAHASAN}

\section{Perkembangan Produksi Bokar dan Faktor-Faktor Yang Mempengaruhinya}

Perkembangan produksi bokar di Kabupaten Batanghari selama periode 20012015 cenderung mengalami trend yang meningkat. Rata-rata pertumbuhan produksi bokar di Kabupaten Batanghari selama lima belas tahun terakhir sebesar 4,67 persen. Pertumbuhan produksi terbesar terjadi pada Tahun 2003 sebesar 22,36 persen. Kemudian konstan naik selama 2 tahun dan mengalami penurunan pada tahun 2006 hingga tahun 2007 sebesar 0,56 persen dan 2,62 persen. Peningkatan kembali terjadi pada 2008 hingga tahun 2015 dan menetap pada angka 73.368 Ton.

Perkembangan luas lahan tanaman menghasilkan perkebunan karet di Kabupaten Batanghari dari Tahun 2001 sampai Tahun 2015 mengalami fluktuasi, namun cenderung terjadi peningkatan setiap tahunnya. Luas lahan tanaman menghasilkan perkebunan karet di Kabupaten Batanghari pada Tahun 2015 mencapai 77.828 Ha terjadi peningkatan dari tahun sebelumnya. Rata-rata pertumbuhan luas lahan tanaman menghasilkan di Kabupaten Batanghari selama lima belas tahun terakhir sebesar 2,89 persen. Pertumbuhan terbesar terjadi pada Tahun 2003 sebesar 24,48 persen. Meningkatnya luas lahan tanaman menghasilkan di Kabupaten Batanghari selama beberapa tahun merupakan dampak dari perluasan lahan perkebunan karet di provinsi Jambi. Peningkatan luas lahan tanaman menghasilkan secara tidak langsung mempengaruhi tingginya produksi bokar.

Perkembangan luas lahan tanaman tua perkebunan karet di Kabupaten Batanghari dari Tahun 2001 sampai Tahun 2015 relatif rendah dan cenderung mengalami penurunan. Selama periode 2001-2015 luas lahan tanaman tua perkebunan karet di Kabupaten Batanghari menurun dengan rata-rata penurunan sebesar 7,83 persen. Namun terdapat beberapa periode yang mengalami peningkatan luas lahan tanaman tua perkebunan karet yaitu pada Tahun 2003 sebesar 7,79 persen dan pada Tahun 2005 sebesar 20,60 persen. Menurunnya luas lahan tanaman tua merupakan dampak dari salah satu program revitalisasi yaitu replanting tanaman karet yang telah tua atau rusak.

Perkembangan jumlah curah hujan di Kabupaten Batanghari dari Tahun 2001 sampai Tahun 2015 cenderung mengalami penurunan. Selama periode 2001-2015 jumlah curah hujan di Kabupaten Batanghari menurun dengan rata-rata penurunan sebesar 7,11 persen. Namun terdapat beberapa periode yang mengalami peningkatan jumlah curah hujan karet yaitu pada Tahun 2003 sebesar 11,5 persen dan pada Tahun 2007 sebesar 6,96 persen. 
Perkembangan jumlah hari hujan di Kabupaten Batanghari dari Tahun 2001 sampai Tahun 2015 berfluktuasi namun cenderung mengalami penurunan. Selama periode 2001-2015 jumlah hari hujan di Kabupaten Batanghari menurun dengan rata-rata penurunan sebesar 4,06 persen. Namun terdapat beberapa periode yang mengalami peningkatan jumlah curah hujan karet yaitu pada Tahun 2003 sebesar 34,16 persen dan pada Tahun 2007 sebesar 28,16.

Perkembangan jumlah tenaga kerja perkebunan karet di Kabupaten Batanghari dari Tahun 2001 sampai Tahun 2015 secara konstan mengalami peningkatan setiap tahunnya. Rata-rata perkembangan jumlah tenaga kerja perkebunan karet di Kabupaten Batanghari selama lima belas tahun terakhir adalah sebesar 1,57 persen. Pertumbuhan terbesar terjadi pada Tahun 2008 sebesar 5,69 persen. Jumlah Tenaga Kerja pada perkebunan karet di Kabupaten Batanghari pada mencapai angka tertinggi pada Tahun 2015 mencapai 38.938 orang.
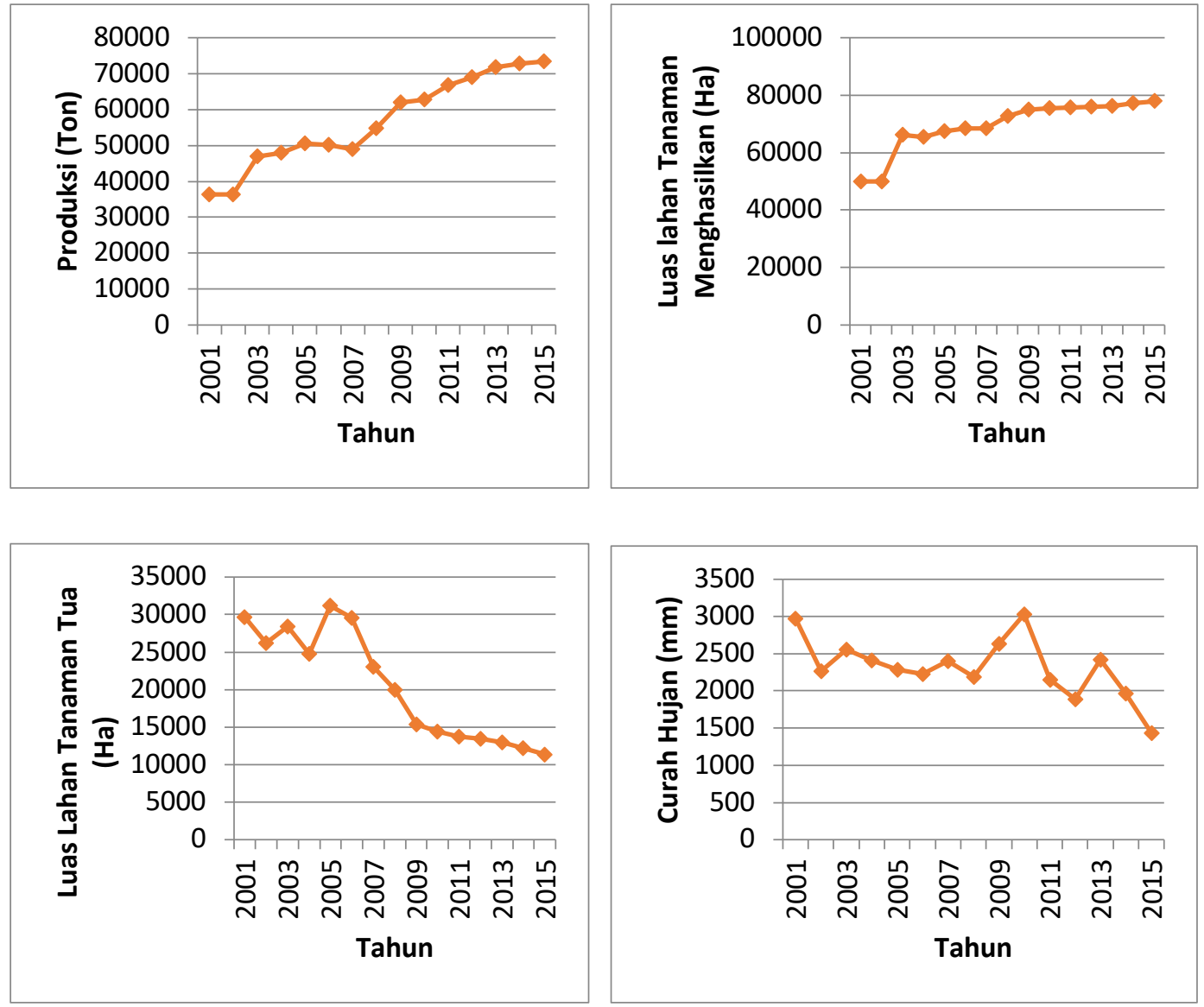


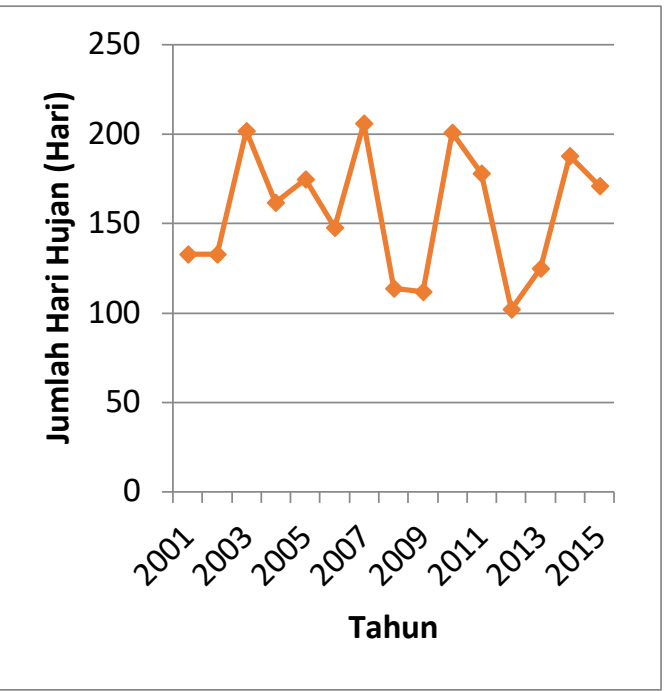

(e)

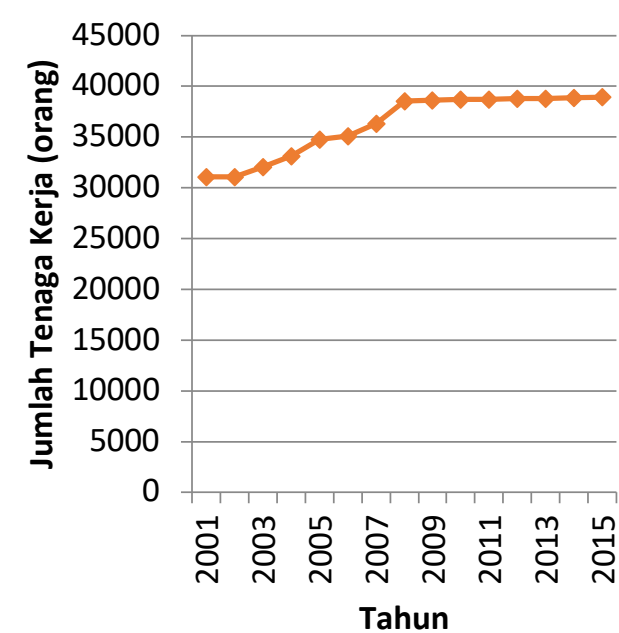

(f)

Gambar: (a) Grafik Produksi Bokar; (b) Grafik Luas Lahan Tanaman Menghasilkan; (c) Grafik Luas Lahan Tanaman Tua ; (d) Grafik Curah Hujan ; (e) Grafik Jumlah Hari Hujan; (f) Grafik Jumlah Tenaga Kerja

Faktor-Faktor yang Mempengaruhi Produksi Bokar di Kabupaten Batanghari Hasil Regresi Linear Berganda

Tabel 1. Hasil pengujian dengan regresi

\begin{tabular}{crrrr}
\hline Variable & Coefficient & Std. Error & t-Statistic & Prob. \\
\hline \hline TM & 0.643092 & 0.144422 & 4.452872 & 0.0016 \\
TT & -0.491336 & 0.203509 & -2.414327 & 0.0390 \\
CH & -1.243384 & 2.242936 & -0.554355 & 0.5928 \\
JHH & -8.663650 & 22.35954 & -0.387470 & 0.7074 \\
JTK & 0.606511 & 0.254028 & 2.387581 & 0.0407 \\
C & -3012.753 & 19087.56 & -0.157839 & 0.0001 \\
\hline \hline & 0.968427 & & & \\
R-squared & 0.950887 & & & 1.216306 \\
F-statistic & 55.21093 & Durbin-Watson stat & & \\
Prob(F-statistic) & 0.000002 & & & \\
\hline \hline
\end{tabular}

Nilai Adjusted R Square yang diperoleh dari hasil regresi yaitu sebesar 0,95 atau 95\%. Hal ini berarti bahwa 95\% produksi bokar dapat dijelaskan oleh variabel luas lahan tanaman menghasilkan, luas lahan tanaman tua, jumlah tenaga kerja, curah hujan, dan jumlah hari hujan sedangkan 5\% lagi dijelaskan oleh variabel lain diluar penelitian.

Pada hasil uji serentak, diketahui bahwa nilai $\mathrm{F}$ hitung adalah sebesar 55,21093 dengan tingkat signifikansi sebesar 0,000002 sedangkan $\alpha=0,05$. Dengan membandingkan nilai $\mathrm{F}$ hitung sebesar 55,21093 dan nilai $\mathrm{F}$ tabel sebesar 3,48, maka dapat diketahui bahwa nilai $F$ hitung lebih besar dari nilai $F$ tabel $(55,21093>3,48)$ yang berarti $\mathrm{H}_{0}$ ditolak. Artinya kelima variabel independent yaitu variabel luas lahan tanaman 
menghasilkan, luas lahan tanaman tua, curah hujan, jumlah hari hujan dan jumlah tenaga kerja secara bersama-sama berpengaruh terhadap produksi bokar. Dari 5 variabel independen yang telah diuji, maka persamaanya menjadi:

$Y=-3012,753+0,643 X_{1}-0,491 X_{2}-1,243 X_{3}-8,663 X_{4}+0,606 X_{5}$

Dari 5 variabel independen yang telah diuji terdapat 3 variabel yang signifikan yaitu luas lahan tanaman menghasilkan $\left(\mathrm{X}_{1}\right)$, luas lahan tanaman tua $\left(\mathrm{X}_{2}\right)$, dan jumlah tenaga kerja $\left(X_{5}\right)$. Karena curah hujan $\left(X_{3}\right)$, dan jumlah hari hujan $\left(X_{4}\right)$ berpengaruh tidak signifikan terhadap produksi bokar, maka persamaanya menjadi:

$Y=-3012,753+0,643 X_{1}-0,491 X_{2}+0,606 X_{5}$

\section{Analisis Pengaruh Faktor-faktor Variabel}

Variabel luas lahan tanaman menghasilkan $\left(\mathrm{X}_{1}\right)$ diduga memiliki hubungan positif terhadap produksi usahatani karet, jika semakin besar luas ukuran lahan sadapan maka produksinya akan semakin meningkat dan sebaliknya. Berdasarkan hasil regresi variabel luas lahan tanaman menghasilkan $\left(X_{1}\right)$ memiliki hubungan yang positif terhadap produksi bokar dengan nilai koefisien regresi sebesar 0,643. Artinya setiap peningkatan luas lahan tanaman menghasilkan sebesar $1 \mathrm{Ha}$ akan menyebabkan peningkatan nilai produksi bokar di Kabupaten Batanghari sebesar 0,643 Ton.

Berdasarkan analisis dengan metode Regresi Berganda, didapatkan bahwa nilai Sig. untuk luas lahan tanaman menghasilkan $\left(\mathrm{X}_{1}\right)$ sebesar 0,0016 lebih kecil bila dibandingkan dengan nilai $\alpha=(0,05)$ dan diketahui bahwa $t_{\text {hitung }}>$ dari $t_{\text {tabel }}(4,45>1,83)$ maka diputuskan tolak Ho terima $\mathrm{H}_{1}$. Hal ini menunjukkan bahwa pada tingkat kepercayaan 95 persen, variabel dugaan yakni luas lahan tanaman menghasilkan terbukti signifikan mempengaruhi produksi bokar di daerah penelitian.

Hasil ini sesuai dengan teori yaitu lahan sebagai salah satu faktor produksi yang cukup besar terhadap usahatani. Besar kecilnya produksi dari usahatani antara lain dipengaruhi oleh luas sempitnya lahan yang digunakan (Mubyarto, 1995). Hasil ini sejalan dengan penelitian Windiari (1998) yang menunjukkan hasil tanaman menghasilkan mempunyai hubungan yang positif, dengan uji t yang signifikan berpengaruh terhadap jumlah produksi. Semakin luas tanaman menghasilkan, berarti semakin banyak pohon produktif yang dapat disadap, sehingga jumlah produksi juga akan semakin meningkat. Hasil ini sejalan pula dengan penelitian Setiadi (2011) yang menunjukan salah satu faktor produksi yang berpengaruh terhadap produksi karet di PTPN IX yaitu luas lahan.

Variabel luas lahan tanaman tua $\left(X_{2}\right)$ memiliki hubungan negatif terhadap produksi bokar dengan nilai koefisien regresi sebesar -0,491. Artinya setiap peningkatan luas lahan tanaman tua sebesar $1 \mathrm{Ha}$ akan menurunkan produksi bokar di Kabupaten Batanghari sebesar 0,491 Ton. Berdasarkan analisis dengan metode Regresi Berganda, didapatkan bahwa nilai Sig. untuk luas lahan tanaman tua $\left(\mathrm{X}_{2}\right)$ sebesar 0,0390 lebih kecil bila dibandingkan dengan nilai $\alpha=(0,05)$ dan diketahui bahwa $t_{\text {hitung }}>$ dari $t_{\text {tabel }}(2,41>$ $1,83)$, maka diputuskan tolak $\mathrm{H}_{\circ}$ terima $\mathrm{H}_{1}$. Hal ini menunjukkan bahwa variabel dugaan yakni luas lahan tua menghasilkan terbukti signifikan untuk mempengaruhi produksi bokar di Kabupaten Batanghari.

Hal ini menunjukkan bahwa pada tingkat kepercayaan 95 persen, variabel dugaan yakni luas lahan tanaman tua terbukti signifikan untuk mempengaruhi produksi bokar di daerah penelitian. Luas lahan tanaman tua berpengaruh negatif dikarenakan pohon karet yang telah berusia tua, sementara pohon karet hanya produktif menghasilkan getah hingga berumur 20-25 Tahun dan setelah itu produktifitas getah akan menurun. Pohon 
karet yang sudah tua dan tidak produktif perlu diremajakan dengan tanaman baru melalui program replanting.

Semakin bertambah umur tanaman semakin meningkat produksi lateksnya. Mulai umur 16 tahun produksi lateksnya dapat dikatakan stabil sedangkan sesudah berumur 28 tahun produksinya akan menurun. Apabila sudah terjadi penurunan produksi lateks karena umur tua, maka tanaman karet sudah waktunya untuk diremajakan (Syamsulbahri, 1996).

Berdasarkan hasil regresi variabel jumlah tenaga kerja $\left(X_{5}\right)$ memiliki hubungan positif terhadap produksi bokar dengan nilai koefisien regresi sebesar 0,606 . Artinya setiap peningkatan jumlah tenaga kerja sebanyak 1 orang maka akan meningkatkan produksi bokar di Kabupaten Batanghari sebesar 0,606 Ton. Berdasarkan analisis dengan metode Regresi Berganda, didapatkan bahwa nilai Sig. untuk jumlah tenaga kerja $\left(X_{5}\right)$ sebesar 0,0407 lebih besar bila dibandingkan dengan nilai $\alpha=(0,05)$ dan diketahui bahwa $t_{\text {hitung }}>$ dari $t_{\text {tabel }}(2,38>1,83)$, maka diputuskan tolak $\mathrm{H}_{\circ}$ terima $\mathrm{H}_{1}$.

Hal ini menunjukkan bahwa pada tingkat kepercayaan 95 persen, variabel jumlah tenaga kerja berpengaruh signifikan terhadap produksi bokar di Kabupaten Batanghari. Jumlah tenaga kerja sangat memegang peranan penting dalam pelaksanaan usahatani karet baik dari pembukaan lahan, pemeliharaan, hingga pemanenan. Variabel jumlah tenaga kerja tersebut memiliki hubungan positif terhadap produktivitas karet. Jika semakin banyak jumlah tenaga kerja maka akan semakin meningkatkan produksi karet atau sebaliknya. Hasil ini penelitian ini dapat diperkuat dengan Teori Mankiw (2000) yang menyatakan bahwa semakin banyak jumlah tenaga kerja maka semakin meningkat jumlah barang yang akan diproduksi. Peningkatan jumlah tenaga kerja akan berimbas pada output yang diproduksi yang juga dapat meningkatkan nilai produksi.

Variabel dugaan yakni variabel curah hujan $\left(X_{3}\right)$, berdasarkan hasil regresi pada tingkat kepercayaan 95 persen berpengaruh tidak signifikan untuk mempengaruhi produksi bokar di Kabupaten Batanghari. Tidak berpengaruhnya variabel curah hujan, disebabkan karena petani karet pada daerah penelitian telah melakukan teknik budidaya tanaman karet dengan baik, penggunaan pupuk dengan efektif dan di dukung dengan ekologi yang cocok dengan pertumbuhan tanaman karet. Selain itu adanya pemeliharaan cover crop (tanaman penutup tanah) pada perkebunan karet sehingga dapat mencegah erosi atau aliran permukaan (run off) yang berdampak efektifnya penyerapan unsur hara dan pupuk, melindungi tanah dari sinar matahari yang terlalu terik dan dapat juga melindungi permukaan tanah dari air hujan, meningkatkan kandungan bahan organik dan hara tanah, dan meningkatkan produksi karet.

Hasil ini sesuai dengan penelitian Manurung (2015), yang menyatakan variabel curah hujan berpengaruh tidak nyata terhadap peningkatan produksi lateks pada tanaman karet berumur 6, 10 dan 14 tahun di kebun PT. Bridgestone Sumatra Rubber Estate Dolok Merangir. Tinggi rendahnya produktivitas tanaman dipengaruhi oleh faktor biologi dari tanaman, tanah dan alam bebas. Keadaan tata air dan udara yang baik dan seimbang menyebabkan akar tanaman dengan mudah dapat menyerap unsur hara. Selain itu adanya faktor lain yang mendukung pertumbuhan yang baik dan seimbang yang dapat membantu memperlancar unsur hara yang dapat meningkatkan produktivitas tanaman, sehingga curah hujan berpengaruh tidak nyata.

Hal yang sama pada variabel dugaan yakni jumlah hari hujan $\left(\mathrm{X}_{4}\right)$ pada tingkat kepercayaan 95 persen, variabel dugaan yakni jumlah hari hujan berpengaruh tidak signifikan terhadap produksi bokar di Kabupaten Batanghari. Hasil ini berbeda dengan penelitian Windiari (1998) yang menunjukkan hasil regresi dengan variabel jumlah hari hujan signifikan berpengaruh terhadap jumlah produksi karet. Tidak berpengaruhnya variabel jumlah hari hujan terhadap produksi karet di Kabupaten dapat dijelaskan 
berkaitan dengan frekuensi dan intensitas penyadapan saat musim hujan yaitu dengan menggantikan hari sadap yang tidak dapat dilaksanakan pada saat turun hujan di hari saat tidak turun hujan, selain itu dipengaruhi oleh faktor lain seperti klon karet, kesuburan tanah, suhu udara, angin, ketinggian tempat yang mendukung pertumbuhan tanaman, sehingga produktivitas tanaman karet tetap terjaga dengan baik.

\section{KESIMPULAN}

Selama kurun waktu Tahun 2001 hingga Tahun 2015, secara umum perkembangan produksi bokar di Kabupaten Batanghari cenderung naik dan mengalami peningkatan setiap tahunnya dengan rata-rata 4,67 persen, walaupun terjadi penurunan produksi pada Tahun 2006 dan 2007. Hal yang sama pada luas lahan tanaman menghasilkan perkebunan karet di Kabupaten Batanghari mengalami fluktuasi cenderung mengalami peningkatan setiap tahunnya dengan rata-rata 2,89 persen, namun terjadi penurunan pada Tahun 2004 dan 2007. Perkembangan luas lahan tanaman tua perkebunan karet, curah hujan dan jumlah hari hujan di Kabupaten Batanghari relatif rendah dan cenderung mengalami penurunan. Selama periode 2001-2015 luas lahan tanaman tua perkebunan karet di Kabupaten Batanghari menurun dengan rata-rata penurunan sebesar 7,83 persen, curah hujan 7,11 persen, dan jumlah hari hujan 4,06 persen. Sedangkan perkembangan jumlah tenaga kerja di Kabupaten Batanghari cenderung meningkat setiap tahunnya dengan rata-rata 1,57 persen.

Hasil regresi menunjukkan bahwa model peningkatan produksi di Kabupaten Batanghari cukup dipercaya untuk menjelaskan pengaruh faktor-faktor produksi terhadap peningkatan produksi bokar, dimana variabel-variabel independen dalam penelitian ini yaitu oleh luas lahan tanaman menghasilkan, luas lahan tanaman tua, curah hujan, jumlah hari hujan dan jumlah tenaga kerja secara bersama-sama berpengaruh signifikan terhadap produksi bokar di Kabupaten Batanghari. Artinya setiap terjadi kenaikan ataupun penurunan pada faktor-faktor tersebut, secara bersama-sama akan meningkatkan ataupun menurunkan produksi bokar di Kabupaten Batanghari. Secara parsial faktor-faktor yang mempengaruhi produksi bokar di Kabupaten Batanghari adalah luas lahan tanaman menghasilkan, luas lahan tanaman tua dan jumlah tenaga kerja, sementara curah hujan dan jumlah hari hujan secara parsial berpengaruh tidak signifikan terhadap produksi bokar.

\section{DAFTAR PUSTAKA}

Direktorat Jenderal Industri Agro. 2013. Ini 5 Negara Produsen Karet Terbesar Di Dunia. Diunduh dari http://agro.kemenperin.go.id. (Diakses tanggal 15 Mei 2015).

Gujarati, Damodar N. 2003. Basic Econometrics. Fourth Edition. International Edition. McGraw Hill., New York.

Gujarati, Damodar N dan Porter, Dawn C. 2010. Dasar-dasar Ekonometrika. Edisi Kelima. Salemba Empat. Jakarta.

Manurung, Margareth Thacher. 2015. Pengaruh Curah Hujan dan Hari Hujan Terhadap Produksi Tanaman Karet (Hevea Brasiliensis Muell-arg) umur 6, 10, 14 tahun pada PT. Bridgestone Sumatera Rubber Estate Dolok Merangir. Fakultas Pertanian. Universitas Sumatera Utara. Medan. Diunduh dari http://repository.usu.ac.id/handle/123456789/22975. (Diakses tanggal 1 Desember 2015)

Mubyarto.1995. Pengantar Ekonomi Pertanian. LP3ES. Jakarta. 
Parhusip, AB. 2008. Potret Karet Alam Indonesia. Economic Review No. 213.

Priyatno, D. 2014. SPSS 22 Pengolah Data Terpraktis. Andi. Yogyakarta.

Setiadi.2010.Faktor-Faktor yang Mempengaruhi Produksi Karet PT. Perkebunan Nusantara

IX(Persero).Diunduhdarihttp://etd.repository.ugm.ac.id/index.php?act=view\& buku id=54487\&mod=penelitian detail\&sub=PenelitianDetail\&typ=html. (Diak sestanggal 18 Juni 2015).

Syamsulbahri. 1996. Bercocok Tanam Tanaman Perkebunan Tahunan. Gajah Mada University. Yogyakarta. $177 \mathrm{hlm}$.

Tribunnews. 2011. Diunduh dari http://jambi.tribunnews.com/2011/11/06/petani-karetdi-batanghari-bakal-dililit-utang (Diakses tanggal 01 Maret 2016).

Widarjono, Agus. 2005. Ekonometrika Pengantar dan Aplikasinya. (Edisi Pertama). Yogyakarta: Ekonisia

Windiari Dwi, Widyastuti. 1998. Analisis Fungsi Produksi Dan Fungsi Biaya Pada Perusda Perkebunan Tlogo - Tuntang. [tesis]. Program Pasca Sarjana. Universitas Diponegoro. 